\title{
Bacteriuria in Pregnancy and Infection in Amniotic Fluid and Infant
}

\author{
J. A. IVES, ${ }^{\star}$ G. D. ABBOTT, $\uparrow$ and R. R. BAILEY $\ddagger$ \\ From the Department of Obstetrics, Christchurch Women's Hospital, and Departments of Renal Medicine and Paediatrics, \\ Christchurch Hospital, Christchurch, New Zealand
}

\begin{abstract}
Ives, J. A., Abbott, G. D., and Bailey, R. R. (1971). Archives of Disease in Childhood, 46, 82. Bacteriuria in pregnancy and infection in amniotic fluid and infant. Women with asymptomatic bacteriuria during pregnancy had sterile amniotic fluid at the time of delivery.

There was no evidence that maternal urinary infection was associated with infection in the infant.
\end{abstract}

Patrick (1967) reported that some women with asymptomatic bacteriuria during pregnancy had infected amniotic fluid at term. Furthermore, bacterial infection was detected in umbilical vein blood, the placenta, and the urinary tract of infants born to mothers with urinary tract infection.

During a survey to assess the incidence of asymptomatic bacteriuria in a population of pregnant New Zealand women (Bailey, 1970) and their infants (Abbott, to be published), some of the patients had a specimen of amniotic fluid cultured. The delivered infants also had a blood and urine culture performed.

\section{Method}

Twenty women with asymptomatic bacteriuria were studied. These patients, selected at random, were taking part in a double blind trial to assess the effect of eradication of the bacteriuria on the incidence of acute pyelonephritis in pregnancy (Bailey, 1970). Bacteriuria was diagnosed when a bacterial growth was obtained from a specimen of urine obtained by suprapubic bladder aspiration (Bailey and Little, 1969). 10 of the infected women had the urinary infection eradicated by a continuous nightly dose of $100 \mathrm{mg}$ nitrofurantoin. The other 10 patients received an identical placebo tablet. All patients given the placebo tablets had bacteriuria at the time of delivery. No woman or infant developed lower urinary tract symptoms or clinical acute pyelonephritis during the observation period.

\footnotetext{
Received 29 June 1970.

Present address:

^Northampton General Hospital.

tHospital for Sick Children, Toronto, Ontario, Canada.

$\ddagger$ Department of Medicine, Charing Cross Hospital Medical School, Fulham Hospital, London W.6.
}

Specimens of amniotic fluid were obtained during labour and before rupture of the membranes. The vulva, perineum, and vagina were swabbed with chlorhexidine obstetric cream $(1 \% \mathrm{w} / \mathrm{w})$ and sterile dressing guards applied. A hind-water membrane rupture was performed with a Drew-Smythe catheter and a midstream sample of liquor was collected into a sterile universal container.

Within 6 to 12 hours of delivery a specimen of blood was taken by needle from an external jugular vein of each infant and introduced into standard blood culture media. All neonates had a voided midstream specimen of urine taken for culture. These collections were obtained by a specially employed registered nursemidwife. If the bacterial count exceeded 10,000 colonies per $\mathrm{ml}$ a specimen was obtained for culture by suprapubic bladder aspiration.

Studies were made on 23 women without urinary infection in a similar manner to those with bacteriuria. The amniotic fluid specimen was obtained at the time of surgical induction of labour for postmaturity, preeclampsia, or hypertension.

Specimens of urine and amniotic fluid were immediately placed at $4^{\circ} \mathrm{C}$ and cultured within 4 hours of collection on blood agar and MacConkey medium. Quantitative cultures were performed using a pour plate technique (Mackie and McCartney, 1960).

\section{Results}

All women with successfully treated or persistent bacteriuria in pregnancy were found to have sterile amniotic fluid. One woman with sterile urine during pregnancy and in the puerperium had over 100,000 Streptococcus faecalis per $\mathrm{ml}$ in the amniotic fluid at the time of delivery (Table). This patient had no clinical evidence of infection. None of the infants born to mothers with bacteriuria had 
TABLE

Cultures of Amniotic Fluid, Neonatal Venous Blood, and Neonatal Urine from Women With and Without Bacteriuria in Pregnancy

\begin{tabular}{|c|c|c|c|c|}
\hline Group & No. Examined & $\begin{array}{l}\text { No. Infected } \\
\text { Amniotic Fluid }\end{array}$ & $\begin{array}{c}\text { Infants with } \\
\text { Infected Blood }\end{array}$ & $\begin{array}{l}\text { Infants with } \\
\text { Infected Urine }\end{array}$ \\
\hline $\begin{array}{l}\text { Women with persistent bacteriuria } \\
\text { Women with treated bacteriuria } \\
\text { Women with no bacteriuria }\end{array}$ & $\begin{array}{l}10 \\
10 \\
23\end{array}$ & $\begin{array}{l}0 \\
0 \\
1\end{array}$ & $\begin{array}{l}0 \\
0 \\
0\end{array}$ & $\begin{array}{l}0 \\
0 \\
1\end{array}$ \\
\hline
\end{tabular}

infection detected in the blood-stream or urinary tract. One infant born to a woman with both sterile urine and amniotic fluid had an Esch. coli infection in the bladder.

\section{Discussion}

Patrick (1967) found infected amniotic fluid in 3 and possibly 4 out of 8 women with persistent pregnancy bacteriuria. No blood cultures were obtained from these women and no comment made as to whether the women with infected liquor had acute pyelonephritis. 3 women with treated bacteriuria and 8 with sterile urine had uninfected amniotic fluid.

There is considerable evidence that amniotic fluid may have antibacterial properties (Cattaneo, 1949; Gusdon, 1962; Galask and Snyder, 1968), though Walsh, Hildebrandt, and Prystowsky (1965) concluded that it might act as a bacterial nutrient.

The present study demonstrated sterile amniotic fluid in women with a persistent asymptomatic urinary tract infection, and also in those patients where the bacteriuria had been successfully eradicated. No explanation was available for the infection detected in the amniotic fluid of one woman with sterile urine who had a surgical induction of labour because of pre-eclampsia.

It was also shown by Patrick (1967) that 6 out of 19 bacteriuric women had infection in the umbilical cord blood. Of 12 women with treated bacteriuria studied by the same author, 2 also had infection in a specimen of umbilical venous blood. In some of the women evidence of infection (leucocytic infiltration) was found in the placentae and cords.

The infants born to bacteriuric mothers in the present study showed no infect:on in the blcodstream or renal tract. On the contrary, Patrick (1967) observed that one-quarter of infants born to asymptomatic bacteriuric mothers had a single bag collected urine specimen containing in excess of 100,000 coliform organisms per $\mathrm{ml}$. This result is of doubtful significance for it has been shown that as many as two-thirds of positive urine cultures carefully collected by the adhesive bag technique were false positive results, when compared with specimens collected by suprapubic bladder aspiration (Shannon, Sepp, and Rose, 1969).

In a study from this department a $1 \%$ incidence of asymptomatic neonatal bacteriuria was found. The diagnosis of infection was similarly made by obtaining urine by bladder aspiration. This figure was the same in infants whether they were born to mothers with or without an asymptomatic urinary tract infection (Abbott, to be published). However, in some neonates this bacteriuria cleared spontaneously after delivery (Abbott, 1970).

Furthermore in a larger survey (Bailey, 1970) we have not been able to confirm the work of Kass (1962) and Patrick (1967) that women with bacteriuria in pregnancy have an increased perinatal mortality rate, lowered infant birthweight, reduced gestation interval, or an increase in the incidence of congenital fetal abnormalities, especially major defects in dorsal midline fusion.

Despite the limited number of patients reported here, the results do not support the contention of Patrick (1967) that asymptomatic maternal urinary tract infection may lead to infection in the amniotic fluid and fetus.

We thank Mr. G. Louisson, Superintendent, Christchurch Women's Hospital, for allowing the patients to be studied. We are also grateful to Sisters L. Berry, L. Bugden, and J. Worrall for technical assistance.

\section{REFERENCES}

Abbott, G. D. (1970). Transient asymptomatic bacteriuria in infancy. British Medical fournal, 1, 207.

Bailey, R. R. (1970). Urinary infection in pregnancy. New Zealand Medical fournal, 71, 216.

- and Little, P. J. (1969). Suprapubic bladder aspiration in diagnosis of urinary tract infection. British Medical fournal, $1,293$.

Cattaneo, P. (1949). Potere lisozimico del liquido amniotico e potere antilisozimico del meconio. Ricerche sperimentali. Clinica Ostetrica e Ginecologica, 51, 60.

Galask, R. P., and Snyder, I. S. (1968). Bacterial inhibition by amniotic fluid. American fournal of Obstetrics and Gynecology, 102. 949.

Gusdon, J. P. (1962). A bactericidin for Bacillus subtilis in pregnancy. Fournal of Immunology, 88, 494. 
Kass, E. H. (1962). Pyelonephritis and bacteriuria. Annals of Internal Medicine, 56, 46.

Mackie, T. J., and McCartney, J. E. (1960). Handbook of Bacteriology, 10th ed., p. 303. Ed. by R. Cruickshank. Livingstone, Edinburgh.

Patrick, M. J. (1967). Influence of maternal renal infection on the foetus and infant. Archives of Disease in Childhood, 42, 208.

Shannon, F. T., Sepp, E., and Rose, G. R. (1969). The diagnosis of bacteriuria by bladder puncture in infancy and childhood. Australian Paediatric fournal, 5, 97.
Walsh, H., Hildebrandt, R. J., and Prystowsky, H. (1965). Growth inhibition factors in amniotic fluid. American fournal of Obstetrics and Gynecology, 93, 590.

Correspondence to R. R. Bailey, Department of Medicine, Charing Cross Hospital Medical School, Fulham Hospital, London W.6. 